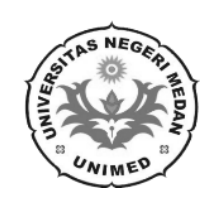

\title{
PENGARUH KOMITE AUDIT, REPUTASI KAP, DAN LEVERAGE TERHADAP \\ INTEGRITAS LAPORAN KEUANGAN PADA PERUSAHAAN MANUFAKTUR YANG TERDAFTAR DI BURSA EFEK INDONESIA TAHUN 2015- 2017
}

\author{
GORA M.O SAGALA, Jumiadi A.W \\ Universitas Negeri Medan
}

\begin{abstract}
Abstrak
Permasalahan dalam penelitian ini adalah karena banyaknya skandal manipulasi laporan keuangan sehingga membuat tingkat kepercayaan masyrakat berkurang terhadap laporan keuangan yang disajikan. Penelitian ini bertujuan untuk mengetahui pengaruh Komite Audit, Reputasi KAP, dan Leverage terhadap Integritas Laporan Keuangan yang terdaftar di BEI. Populasi penelitian ini adalah perusahaan Manufaktur yang terdaftar di BEI Periode 2015-2017. Dari 143 perusahaan yang terdaftar, dipilih 31 perusahaan sampel dengan menggunakan metode porposive sampling. Data yang digunakan dalam penelitian ini adalah data sekunder, dengan mengunduh laporan keuangan dari situs www.idx.co.id. Teknik analisis data yang digunakan adalah statistik deskriptif, uji asumsi klasik dan analisis regresi berganda. Hasil penelitian ini menunjukkan bahwa variabel Komite Audit, Reputasi KAP dan Leverage berpengaruh secara simultan terhadap integritas laporan keuangan. Hasil ini menunjukkan bahwa Komite Audit, Reputasi KAP dan Leverage merupakan faktor-faktor yang harus diperhatikan perusahaan dalam meningkatkan integritas laporan keuangan. Sementara secara parsial Reputasi KAP dan Leverage berpengaruh secara signifikan terhadap integritas Laporan Keuangan dan Komite Audit tidak berpengaruh terhadap integritas laporan keuangan. Kesimpulan dari penelitian ini adalah secara parsial hanya variabel komite audit yang tidak berpengaruh terhadap integritas laporan keuangan. Secara simultan variabel Komite Audit, Reputasi KAP, dan Leverage berpengaruh terhadap integritas laporan keuangan.
\end{abstract}

Kata kunci: Integritas Laporan Keuangan, Komite Audit, Reputasi KAP, Leverage 


\section{Pendahuluan}

Tentu suatu perusahaan haruslah menyajikan laporan keuangan sebagai bentuk pertanggungjawaban kepada pihak-pihak yang berkepentingan. Tujuan laporan keuangan adalah menyediakan informasi yang menyangkut posisi keuangan, kinerja, serta perubahan posisi keuangan suatu perusahaan yang bermanfaat bagi sejumlah besar pemakai dalam pengambilan keputusan ekonomi. Informasi dalam laporan keuangan harus disajikan secara benar dan jujur dengan mengungkap fakta sebenarnya yang menjadi kepentingan banyak pihak.

Laporan keuangan merupakan catatan resmi mengenai kegiatan keuangan yang digunakan sebagai informasi secara benar, jujur dan berdaya guna yang mana dapat disebut dengan laporan keuangan disajikan dengan integritas yang tinggi (Verya 2017). Laporan Keuangan adalah suatu penyajian terstruktur dari posisi keuangan dan kinerja keuangan suatu entitas (Ikatan Akuntan Indonesia(IAI) dalam PSAK No.1 tentang Penyajian Laporan Keuangan Revisi 2017). Dengan kata lain, bahwa laporan keuangan adalah gambaran umum keuangan dari sebuah perusahaan yang dimana laporan keuangan ini merupakan suatu informasi yang penting bagi pihak yang berkepentingan terhadap informasi seperti manajer, investor, kreditor dan agen regulator. Laporan keuangan menyajikan informasi mengenai mengenai assset, liabilitas, ekuitas, pendapatan dan beban termasuk keuntungan dan kerugian, kontribusi dari pemilik dalam kapasitasnya sebagai pemilik, juga menceritakan arus kas suatu entitas. Tujuan laporan keuangan adalah untuk memberikan informasi mengenai posisi keuangan, kinerja keuangan, arus kas entitas yang berguna bagi sebagian besar kalangan pengguna laporan dalam pembuatan keputusan ekonomi. Laporan keuangan ini tentu menunjukkan hasil pertanggungjawaban manajemen atas penggunaan sumberdaya yang dipercayakan kepada mereka. Informasi akuntansi yang memiliki integritas yang tinggi akan dapat diandalkan karena merupakan suatu penyajian yang jujur sehingga memungkinkan pengguna informasi akuntansi bergantung pada informasi tersebut.

Oleh karena itu, informasi yang memiliki integritas yang tinggi memiliki kemampuan untuk mempengaruhi keputusan pembaca laporan keuangan untuk membantu membuat keputusan. Financial Accounting Standard Board (FASB) dalam Statement of Financial Accounting Concept No. 2 (SFAC No. 2) mendefenisikan informasi akuntansi sebagai informasi yang disediakan melalui pelaporan keuangan dan berbagai penjelasan yang digunakan sebagai laporan.

Akan tetapi pada saat ini banyak terjadi manipulasi data akuntansi khususnya pada laporan keuangan. Kasus-kasus hukum yang melibatkan manipulasi ini telah meningkat dalam beberapa tahun terakhir. Pada tanggal 2 Desember 2001, dunia perekonomian dikejutkan dengan munculnya berita yang berasal dari Houston di Texas, Amerika. Enron, industry terbesar ketujuh di Amerika, yang sekaligus merupakan perusahaan energi perdagangan terbesar di Amerika menyatakan kebangkrutannya. Yang lebih memprihatinkan, kebangkrutan tersebut bukan dikarenakan perekonomian dunia yang sedang melemah, melainkan disebabkan oleh kesalahan fatal

dalam sistem akuntan mereka. Selama tujuh tahun terakhir, Enron melebih-lebihkan laba dan menutupi hutang-hutang mereka. Akhirnya pada waktu yang singkat, Enron melaporkan kebangkrutannya kepada otoritas pasar modal. (Liputan 6.com, 2014).

Kemudian perusahaan lain yang melakukan manipulasi laporan keuangan perusahaan melakukan penggelembungan angka dengan cara biaya jaringan yang telah dibayarkan oleh pihak WorldCom kepada pihak ketiga dipertanggungjawabkan dengan tidak benar. Dimana biaya jaringan yang seharusnya dilaporkan dalam laporan laba rugi, oleh perusahaan dibebankan kerekening modal. Selain itu, dana cadangan untuk beberapa biaya operasional dinaikkan oleh perusahaaan. Dengan praktik ini, WorldCom berhasil memanipulasi keuntungannya sebesar \$ 2 M (Kalsum, 2015)

Selain itu juga, kasus manipulasi laporan keuangan juga terjadi di Indonesia. Yang pertama, Kasus bank Lippo, kasus ini melakukan pelaporan laporan keuangan ganda pada tahun 2002. Dalam pengumuman laporan keuangan per 30 September 2002 ke publik pada 28 November 2002, Bank Lippo menyebutkan total aktiva perseroan Rp 24 triliun dan laba bersih Rp 98 miliar. Namun, dalam laporan keuangan ke BEJ pada 27 Desember 2002, manajemen menyebutkan total aktiva berkurang menjadi Rp 22,8 triliun dengan rugi bersih Rp 1,3 triliun. Perbedaan laba bersih tersebut karena kemerosotan nilai agunan yang diambil alih (AIDA) dari Rp 2,393 triliun pada laporan publikasi dan Rp 1,42 triliun pada laporan ke BEJ.( Liputan 6.com, 2003) 
Tentu, fenomena-fenomena ini jelas menunjukkan terjadinya manipulasi informasi akuntansi sebagai kegagalan dari integritas laporan keuangan untuk memenuhi informasi para pengguna laporan keuangan tersebut. Dimana seperti yang kita tahu bahwa laporan keuangan ini mengungkapkan laba/kinerja yang dihasilkan oleh perusahaan dalam periode tersebut, yang dimana lewat laporan tersebut akan mendukung keputusan ekonomi perusahaan, akan tetapi karna terjadi manipulasi laporan keuangan maka informasi akan laporan tersebut diragukan kualitasnya.

Faktor pertama yang mempengaruhi integritas laporan keuangan adalah masalah corporate governance. Forum Corporate governance In Indonesia (FCGI, 2011) mendefenisikan Corporate governance sebagai berikut:

Seperangkat peraturan yang mengatur hubungan antara pemegang saham, pengurus (pengelola) perusahaan, pihak kreditur, pemerintah, karyawan serta para pemegang kepentingan intern dan ekstern lainnya yang berkaitan dengan hak-hak dan kewajiban mereka, atau dengan kata lain suatu sistem yang mengatur dan mengendalikan perusahaan.

Di indonesia, corporate governance menjadi isu yang hangat yang selalu ditingkatkan kualitasnya dari tahun ke tahun. Terutama sejak terjadi krisis ekonomi yang melanda negara-negara asia termasuk Indonesia, dan semakin menjadi perhatian akibat banyak terungkapnya kasus-kasus manipulasi laporan keuangan. Di indonesia dan negara-negara asia lainnya yang mengalami krisis ekonomi sejak pertengahan tahun 1997, isu mengenai good corporate governance telah menjadi bahasan penting dalam rangka mendukung pemulihan kegiatan dunia usaha dan pertumbuhan perekonomian setelah masa-masa krisis tersebut.

Siahaan (2017) menyatakan Selain dari pihak perusahaan, auditor eksternal juga harus turut bertanggung jawab terhadap merebaknya kasus-kasus manipulasi akuntansi seperti ini. Profesi akuntan mempunyai peranan penting dalam penyediaan informasi keuangan yang handal bagi pemerintah, investor, kreditor, pemegang saham, karyawan, debitur, juga bagi masyarakat dan pihak-pihak lain yang berkepentingan. Penting bagi pemakai laporan keuangan untuk memandang KAP sebagai pihak yang independen dan kompeten, karena akan mempengaruhi berharga atau tidaknya jasa yang telah diberikan oleh KAP kepada pemakai. Setiap auditor harus mempertahankan integritas dan objektivitas dalam menjalankan tugas dengan bertindak jujur dan tegas sehingga auditor dapat bertindak adil, tanpa dipengaruhi tekanan atau permintaan pihak tertentu untuk memenuhi kepentingan pribadinya. Sinaga (2014) menyatakan kualitas audit yang dilakukan oleh akuntan publik dapat dilihat dari ukuran KAP yang melakukan audit. KAP big four ( Big Four Accounting Firm) di persepsikan akan melakukan audit dengan lebih berkualitas dibandingkan dengan KAP non big four (Non Big Accounting Firm).

\section{Kerangka Teoritis dan Pengembangan Hiotesis}

\subsection{Kerangka Teoritis \\ 2.1.1 Teori Agensi}

Teori Keagenan dalam perkembangannya terbagi menjadi dua aliran meliputi: (1) Positive Theory of Agency, teori ini memfokuskan pada identifikasi situasi ketika pemegang saham dan manajer sebagai agen mengalami konflik dan mekanisme pemerintah yang membatasi self saving dalam diri agen. (2) Principal Agent Literature, memfokuskan pada kontrak optimal antara perilaku dan hasilnya yang secara garis besar penekanannya pada hubungan pemegang saham dan agen (Jensen \& Meckling, 1976).

Teori keagenan dilandasi oleh 3 (tiga) buah asumsi yaitu: (a) asumsi tentang sifat manusia, (b) asumsi tentang keorganisasian dan (c) asumsi tentang informasi. Asumsi tentang sifat manusia menekankan bahwa manusia memiliki

sifat untuk mementingkan diri sendiri (self interest), memiliki keterbatasan rasionalitas (bounded rationality), dan tidak menyukai risiko (risk aversion). Asumsi keorganisasian adalah adanya konflik antar anggota organisasi, efisiensi sebagai kriteria produktivitas, dan adanya Asymmetric Information (AI) antara prinsipal dan agen.Sedangkan asumsi tentang informasi adalah bahwa informasi dipandang sebagai barang komoditi yang bisa diperjual belikan (Eisenhard 1989). 
Perbedaan asimetri informasi dapat terbagi atas dua jenis asymmetric information, yaitu: adverse selection dan moral hazard. Adverse selection, yaitu suatu keadaan dimana prinsipal tidak dapat mengetahui apakah suatu keputusan yang diambil oleh agen benar-benar didasarkan atas informasi yang telah diperolehnya, atau terjadi sebagai sebuah kelalaian dalam tugas.Moral Hazard, yaitu permasalahan yang muncul jika agen tidak melaksanakan hal-hal yang telah disepakati bersama dalam kontrak kerja (Jensen \& Meckling,1976).

Dengan semakin tingginya asimetri informasi antara manajer dengan pemilik yang mendorong pada tindakan manajemen laba oleh manajemen akan memicu semakin tingginya biaya keagenan (agency cost). Jensen \& Mecklingmenyebutkan ada tiga jenis agency cost yakni, (1) monitoring cost yakni biaya pemantauan atas tindakan manajemen, (2) bonding cost yakni biaya untuk mengikat kepentingan manajer terhadap kepentingan pemilik, (3) residual loss yakni kerugian yang diterima pemegang saham atas keputusan manajemen yang tidak optimal (Jensen \& Meckling,1976).

\subsubsection{Teori Sinyal (Signalling Theory)}

Teori sinyal mengemukakan tentang bagaimana seharusnya sebuah perusahaan memberikan sinyal kepada pengguna laporan keuangan. Sinyal ini berupa informasi mengenai apa yang sudah dilakukan oleh manajemen untuk merealisasikan keinginan pemilik. Sinyal dapat berupa promosi atau informasi lain yang menyatakan bahwa perusahaan tersebut lebih baik daripada perusahaan lain. (Antovandra, 2017).

Untuk memastikan pihak-pihak yang berkepentingan menyakini keandalan informasi keuangan yang disampaikan pihak manajemen (agent), perlu mendapat opini dari pihak lain yang independen memberikan pendapat tentang laporan keuangan. Sinyal opini yang independen diberikan oleh Kantor Akuntan Publik (KAP) merupakan sinyal yang mencerminkan keandalan informasi keuangan yang dihasilkan perusahaan yang telah diaudit. Kualitas Kantor Akuntan Publik (KAP) juga dapat memberikan sinyal kepercayaan pihak kepercayaan pihak perusahaan (agent), pemilik (prinsipal, dan pihak-pihak lain yang berkepentingan atas legalitas dan integritas opini yang indpenden dikeluarkan akuntan.

\subsubsection{Integritas Laporan Keuangan}

Integritas secara terminologi berarti mutu, sifat atau keadaan yang menunjukkan kesatuan yang utuh sehingga memiliki potensial dan kemampuan yang memancarkan kewibawaan, kejujuran. Laporan keuangan yang berkualitas adalah laporan keuangan yang memiliki iintegritas dalam penyajiannya. Menurut Suci Atiningsih(2018) "Integritas laporan keuangan adalah sejauh mana laporan keuanganyang disajikan menunjukkan informasi yang benar dan jujur".Informasi akuntansi yang memiliki integritas yang tinggi dapatdiandalkan karena merupakan suatu penyajian yang jujur sehingga memungkinkan pengguna informasi akuntansi bergantung pada informasi tersebut.

Jama'an (2008) menyatakan integritas informasi laporan keuangan menyangkut keandalan informasi akuntansi yang dihasilkan yaitu kejujuran dalam penyajian, dapat dipercaya, dan netralitas yang antara lain dapat dijelaskan sebagai berikut:

1. Kejujuran (faithfullness) berarti informasi harus menggambarkan dengan jujur transaksi serta peristiwa lainnya yang seharusnya disajikan atau yang secara wajar dapat diharapkan untuk disajikan. Jadi, misalnya, neraca harus menggambarkan dengan jujur transaksi serta peristiwa lainnya dalam bentuk aktiva, kewajiban dan ekuitas organisasi pada tanggal pelaporan yang memenuhi kriteria pengakuan.

2. Dapat dipercaya (reliability) berarti bahwa seorang pengguna dapat menggantungkan atau memiliki keyakinana pada informasi yang dilaporkan. 
3. Kejujuran (faithfullness) berarti informasi harus menggambarkan dengan jujur transaksi serta peristiwa lainnya yang seharusnya disajikan atau yang secara wajar dapat diharapkan untuk disajikan.

4. Dapat dipercaya (reliability) berarti bahwa seorang pengguna dapat menggantungkan atau memiliki keyakinana pada informasi yang dilaporkan.

5. Netral (Neutrality) berarti Informasi harus diarahkan pada kebutuhan umum pemakai, dan tidak bergantung pada kebutuhan dan keinginan pihak tertentu.

\subsubsection{Konservatisme}

Menurut Savitri, Enni (2016:24) menyatakan bahwa:

Prinsip konservatisme adalah konsep yang mengakui beban dan kewajiban sesegera mungkinmeskipun ada ketidakpastian tentang hasilnya, namun hanya mengakui pendapatan dan aset ketika sudah yakin akan diterima. Berdasarkan prinsip konservatisme, jika ada ketidakpastian tentang kerugian, Anda harus cenderung mencatat kerugian.Sebaliknya, jika ada ketidakpastian tentang keuntungan, Anda tidak harus mencatat keuntungan.Dengan demikian, laporankeuntungan cenderung menghasilkan jumlah keuntungan dan nilai aset yang lebih rendah demi untuk berjaga-jaga.

Contoh lain dari penerapan prinsip konservatisme adalah LOCOM, di mana persediaandicatat dengan harga yang terendah antara beban pembeliannya atau harga pasar saat ini.

Astria (2011) Mengatakan bahwa konservatisme ini merupakan praktek akuntansi dengan cara mengurangi laba (dan menurunkan nilai aktiva bersih) ketika menghadapi badnews, akan tetapi meningkatkan laba (dan menaikan nilai aktiva bersih) ketika menghadapi goodnews. Untuk itu ketidak pastian dan resiko tersebut harus dicerminkan didalam laporan keuangan agar nilai prediksi dan kenetralan bisa diperbaiki.

\subsubsection{Komite audit}

Komite audit memiliki tugas yang berhubungan dengan kualitas pelaporan keuangan. Keberadaan komite audit diharapkan dapat membantu dewan komisaris melakukan tugasnya dalam mengawasi proses pelaporan keuangan. Selain itu, peran komite audit juga sangat penting karena akan mempengaruhi kualitas penyampaian kinerja perusahaan dalam laporan keuangan yang dilaporkan, karena informasi tersebut merupakan informasi penting bagi stakeholders, khususnya bagi investor dan kreditor dalam menilai perusahaan. Hal ini membuktikan bahwa mekanisme corporate governance mampu mengurangi adanya praktik manipulasi terhadap laporan keuangan yang dilakukan oleh manajer (Komite Nasional Kebijakan Governance, 2006).

Berdasarkan Surat Edaran BEJ, SE-008/BEJ/12-2001, keanggotaan komite audit terdiri dari sekurang-kurangnya tiga orang termasuk ketua komite audit.Anggota komite ini yang berasal dari komisaris hanya sebanyak satu orang, anggota komite yang berasal dari komisaris tersebut merupakan komisaris independen perusahaan tercatat sekaligus menjadi ketua komite audit. Anggota lain yang bukan merupakan komisaris independen harus berasal dari pihak eksternal yang independen.

Komite audit beranggotakan komisaris independen, dan terlepas dari kegiatan manajemen sehari-hari dan mempunyai tanggungjawab utama untuk membantu dewan komisaris dalam menjalankan tanggung jawabnya terutama dengan masalah yang berhubungan dengan kebijakan akuntansi perusahaan, pengawasan internal, dan sistem pelaporan keuangan. Jumlah anggota komite audit disesuaikan besar kecilnya dengan organisasi dan tanggung jawab.

\subsubsection{Reputasi KAP}

Dalam menyampaikan suatu laporan atau informasi mengenai kinerja perusahaan kepada para pengguna laporan keuangan, setiap perusahaan diminta untuk menggunakan jasa Kantor Akuntan Publik (KAP) untuk meningkatkan kredibilitas dari laporan keuangan tersebut. Perusahaan biasanya akan menggunakan jasa KAP yang mempunyai reputasi atau nama baik. Hal ini ditunjukkan dengan KAP yang berafiliasi dengan KAP besar yang berlaku universal yang lebih dikenal dengan Big Four 
Worldwide Accounting Firm (Big Four). Di indonesia terdapat beberapa KAP yang berafiliasi dan menggunakan brand name KAP Big Four, yaitu:

1. Ernst \& Young bekerja sama dengan dengan KAP Purwantono, Sarwoko, Sandjaja

2. Deloitte Touche Tohmatsu beekerja sama dengan KAP Osman Bing Satrio

3. Price Waterhouse Coopers bekerja sama dengan KAP Haryanto Sahari

4. KPMG bekerja sama dengan KAP Sidharta, Sidharta, Widjaja

\subsubsection{Leverage}

Leverage merupakan banyaknya jumlah utang yang dimiliki perusahaan dalam melakukan pembiayaan dan dapat digunakan untuk mengukur besarnya aktiva yang dibiayai dengan utang. Perusahaan yang mempunyai tingkat leverage yang tinggi secara ekonomi dapat menunjukkan beberapa hal. Pertama adalah bahwa perusahaan dapat secara efisien menggunakan pembiayaan dari eksternal untuk meningkatkan nilai dan kekayaan pemegang saham. Kedua yang juga penting adalah bahwa kreditur menyakini rencana bisnis dan prospek perusahaan di masa mendatang dengan memberikan pinjaman dengan jumlah yang relatif besar (Situmeang, 2014:59). Leverage merupakan proporsi total hutang terhadap rata-rata ekuitas pemegang saham. Rasio ini digunakan untuk memberikan gambaran mengenai struktur modal yang dimiliki perusahaan sehingga dapat dilihat tingkat resiko tak tertagihnya suatu utang.

\subsection{Kerangka Berpikir}

\subsubsection{Pengaruh Komite Audit terhadap integritas laporan keuangan}

Komite audit di dalam perusahaan dapat menjadi salah satu upaya dalam mengurangi kecurangan dalam penyajian laporan keuangan sehingga komite audit diharapkan dapat meningkatkan pengawasan terhadap tindakan manajemen yang memungkinkan untuk melakukan manipulasi terhadap laporan keuangan yang mempengaruhi integritas laporan keuangan. Komite audit berfungsi untuk memberikan pandangan mengenai masalah-masalah yang berkaitan dengan kebijakan keuangan, akuntansi, dan pengendalian intern dari perusahaan. Dalam hal pelaporan keuangan, peran dan tanggungjawab komite audit adalah memonitor dan mengawasi audit laporan keuangan dan memastikan agar standar dan kebijaksanaan keuangan yang berlaku terpenuhi, memeriksa ulang laporan keuangan apakah sudah sesuai dengan standar dan kebijaksanaan tersebut dan apakah sudah konsisten dengan informasi lain yang diketahui oleh anggota komite audit, serta menilai mutu pelayanan dan kewajaran biaya yang diajukan auditor eksternal sehingga pada akhirnya mempengaruhi tingkat integritas laporan keuangan.

2.3.2 Pengaruh Reputasi Kantor Akuntan Publik (KAP) terhadap Integritas Laporan Keuangan

KAP besar pada umumnya dianggap sebagai penyedia kualitas audit yang tinggi dan memiliki reputasi tinggi di lingkungan bisnis, serta KAP yang lebih besar juga dianggap lebih mandiri dari KAP yang lebih kecil. KAP besar umumnya pasti akan menjaga reputasinya sehingga pasti akan memberikan kualitas audit yang tinggi. Sehingga semakin besar KAP semakin tinggi integritas laporan keuangan yang dihasilkan.

\subsubsection{Pengaruh Leverage terhadap integritas laporan keuangan}

Perusahaan dengan tingkat leverage yang tinggi akan memiliki kecenderungan untuk melakukan pengungkapan laporan keuangan yang lebih luas jika dibandingkan dengan perusahaan yang memiliki leverage lebih rendah. Hal ini didorong agar para pemegang obligasi perusahaan tidak ragu terhadap kinerja manajemen perusahaan dan hak-hak mereka sebagai kreditur dapat terpenuhi.Oleh karena itu, perusahaan dengan leverage yang tinggi lebih memilih untuk meningkatkan integritas laporan keuangannya di mata para stakeholder, khususnya bagi para kreditur. (Verya, 2017)

Berdasarkan penjelasan di atas maka dapat digambarkan kerangka pemikiran sebagai berikut: 


\section{Kerangka Berpikir}

Gambar 2.1

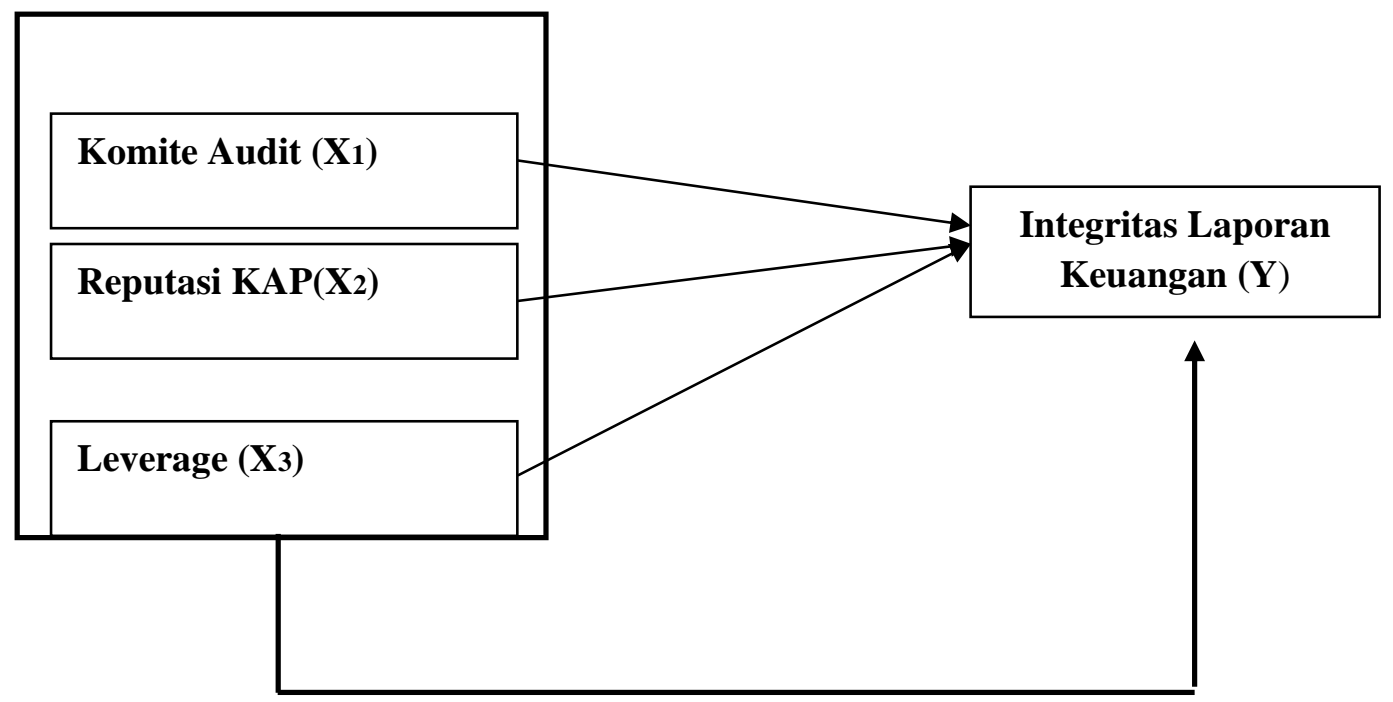

Keterangan :

$\longrightarrow$ : pengaruh variabel $\mathrm{X} 1, \mathrm{X} 2$ dan $\mathrm{X} 3$ terhadap variabel $\mathrm{Y}$ secara parsial

\subsection{Hipotesis Penelitian}

Berdasarkan kajian teoritis hasil penelitian terdahulu dan kerangka berpikir yang telah dikemukan sebelumnya, maka peneliti mengajukan hipotesis penelitian sebagai berikut:

HI: Komite audit berpengaruh terhadap integritas laporan keuangan pada perusahaan manufaktur yang terdaftar di BEI

H2: Reputasi KAP berpengaruh terhadap integritas laporan keuangan pada perusahaan manufaktur yang terdaftar di BEI

H3: Leverage berpengaruh terhadap integritas laporan keuangan pada perusahaan manufaktur yang terdaftar di BEI

H4: Komite Audit, Reputasi KAP, Leverage berpengaruh simultan terhadap integritas laporan keuangan pada perusahaan manufaktur yang terdaftar di BEI

\section{METODOLOGI PENELITIAN}

\subsection{Lokasi dan Waktu Penelitian}

Penelitian ini dilakukan pada perusahaan manufaktur yang terdaftar di Bursa Efek Indonesia pada tahun 2015-2017 dengan mengakses situs www.idx.co.id. Penelitian ini dilakukan pada bulan april 2019 sampai dengan selesai.

\subsection{Populasi dan Sampel}

Populasi adalah seluruh kumpulan elemen yang menunjukkan ciri-ciri tertentu yang dapat digunakan untuk membuat kesimpulan (Sanusi, 2016:87). Teknik pengambilan sampel yang digunakan dalam penelitian ini menggunakan metode purposive sampling. Purposive sampling adalah cara pengambilan sampel yang didasarkan pada pertimbangan-pertimbangan tertentu. Pertimbangan yang dilakukan peneliti dalam pemilihan sampel pada penelitian ini adalah:

1. Menerbitkan Laporan Keuangan untuk periode 2015-2017.

2. Laporan keuangan perusahaan yang mengalami kerugian periode 2015-2017

3. Laporan keuangan perusahaan Manufaktur disajikan dalam mata uang Rupiah 
4. Data yang dibutuhkan terkait dengan variabel penelitian disajikan dengan lengkap selama periode 2015-2017.

\subsection{Variabel Penelitian dan Defenisi Operasional}

\subsubsection{Variabel Penelitian}

Variabel penelitian adalah suatu atribut atau sifat / nilai dari orang objek atau kegiatan yang mempunyai variasi tertentu yang ditetapkan oleh penelitian untuk dipelajari dan ditarik kesimpulan. (Sugiyono,2008).

Variabel independen adalah variabel yang menjelaskan atau mempengaruhi variabel yang lain. Penelitian ini menggunakan Komite Audit $\left(\mathrm{X}_{1}\right)$, Reputasi KAP $\left(\mathrm{X}_{2}\right)$, Leverage $\left(\mathrm{X}_{3}\right)$.

Variabel dependen adalah variabel yang dijelaskan atau dipengaruhi oleh variabel independen. Variabel dependen pada penelitian ini adalah Integritas Laporan Keuangan.

\subsubsection{Definisi Operasional Variabel}

\subsubsection{Variabel Dependen}

1. Integritas Laporan Keuangan

Dalam penelitian ini integritas laporan keuangan diukur dengan menggunakan konservatisme. Pengukuran indeks konservatisme sebagai proksi integritas laporan keuangan dengan menggunakan market to book ratio, yaitu:

$$
\text { MBVit }=\frac{\text { Harga Pasar Saham }}{\text { Nilai Buku Saham }}
$$

\subsubsection{Variabel Independen}

1. Komite Audit .

Komite audit dalam penelitian ini diukur dengan menggunakan frekuensi rapat anggota komite audit yang terdapat di dalam perusahaan selama satu tahun (Pamudji, Sugeng dan Aprillya Trihartati, 2010).

\section{Reputasi KAP}

Variabel reputasi KAP dalam penelitian ini diukur dengan menggunakan variabel dummy. Jika perusahaan klien diaudit oleh KAP yang menggunakan brand name KAP big four maka akan diberi nila 1. Jika perusahaan klien diaudit oleh KAP yang tidak menggunakan brand name KAP non big four maka akan diberi nilai 0 .

\section{Leverage}

Leverage merupakan banyaknya jumlah utang yang dimiliki perusahaan dalam melakukan pembiayaan dan dapat digunakan untuk mengukur besarnya modal yang digunakan untuk membiayai utang.

$$
\text { Leverage }=\frac{\text { Total Hutang }}{\text { Total Ekuitas }}
$$

Tabel 3.1 Operasional Variabel Penelitian

\begin{tabular}{|c|c|c|c|}
\hline No & Variabel & Indikator & $\begin{array}{c}\text { Skala } \\
\text { Pengukuran }\end{array}$ \\
\hline
\end{tabular}




\begin{tabular}{|c|c|c|c|}
\hline 1 & $\begin{array}{l}\text { Integritas } \\
\text { Laporan } \\
\text { Keuangan (Y) }\end{array}$ & $\begin{array}{l}\text { Market to book ratio } \\
\qquad M B V i t=\frac{\text { Harga Pasar Saham }}{\text { Nilai Buku Saham }}\end{array}$ & Rasio \\
\hline 2 & $\begin{array}{l}\text { Komite Audit } \\
\text { (X1) }\end{array}$ & Frekuensi Rapat Komite Audit & Nominal \\
\hline 3 & $\begin{array}{l}\text { Reputasi KAP } \\
\text { (X2) }\end{array}$ & $\begin{array}{l}\text { Angak } 1 \text { diberikan jika auditor yang mengaudit } \\
\text { perusahaan merupakan auditor dari KAP big } \\
\text { four dan } 0 \text { jika ternyata perusahaan yang diaudit } \\
\text { oleh KAP non big four (dummy) }\end{array}$ & Nominal \\
\hline 4 & Leverage (X3) & Leverage $=\frac{\text { Total Hutang }}{\text { Total Ekuitas }}$ & Rasio \\
\hline
\end{tabular}

\subsection{Teknik Pengumpulan Data}

Teknik pengumpulan data yang digunakan adalah dengan mengambil data-data yang diperoleh dari laporan keuangan dan laporan tahunan yang dipublikasikan di Bursa Efek Indonesia melalui situs www.idx.co.id

\subsection{Teknik Analisis Data \\ 4.5.1 Statistik Deskriptif}

Statistik deskriptif memberikan gambaran atau deskripsi suatu data yang dilihat dari nilai ratarata (mean), standar deviasi, nilai maksimum dan minimum (Ghozali, 2013:19). Analisis deskriptif ditujukan untuk memberikan gambaran atau deskripsi data dari variabel-variabel yang diteliti.

\subsubsection{Uji Asumsi Klasik}

\subsubsection{Uji Normalitas}

Uji normalitas adalah untuk melihat apakah nilai residual terdistribusi normal atau tidak. Uji normalitas bertujuan untuk menguji apakah dalam model regresi, variabel pengganggu atau residual memiliki distribusi normal. Pada dasarnya normalitas dapat dideteksi dengan melihat titik-titik (penyebaran data) pada sumbu diagonal dari grafik atau dengan cara melihat histogram dari residualnya (Ghozali, 2013).

\subsubsection{Uji Multikolinieritas}

Multikolonieritas dapat dilihat dengan menggunakan dua cara yaitu menghitung variance inflation factor (VIF) dan nilai tolerance. Kedua ukuran ini menunjukkan setiap variabel manakah yang dijelaskan oleh variabel independen lainnya. Nilai tolerance mengukur variabel bebas terpilih yang tidak dapat dijelaskan oleh variabel bebas lainnya. Variance inflation factor (VIF) dihitung dengan rumus VIF 1/Tolerance. Nilai cutoff yang digunakan pada penelitian ini unutk menunjukkan adanya multikolinieritas adalah nilai Tolerance $<0,10$ atau sama dengan nilai VIF $>10$ (Ghozali, 2013:105).

\subsubsection{Uji Autokorelasi}

Uji Autokorelasi bertujuan apakah dalam model regresi linear ada kolerasi anatara kesalahan pengganggu periode $t$ dengan kesalahan pengganggu pada periode $t-1$ (sebelumya). Model regresi yang baik adalah regresi yang bebas dari autokolerasi. Autokorelasi muncul karena observasi yang berurutan sepanjang waktu berkaitan satu sama lainnya. Masalah ini timbul karena residual (kesalahan pengganggu) tidak bebas dari satu observasi ke observasi lainnya (Ghozali, 2016).

\subsubsection{Uji Heteroskedestisitas}

Deteksi ada tidaknya heterokedastisitas dapat dilakukan dengan melihat ada tidaknya pola tertentu pada grafik Scatterplot antara nilai prediksi variabel terikat (ZPRED) dengan residualnya (SRESID) dimana sumbu Y adalah yang telah diprediksi, sedangkan sumbu X adalah residual. Jika ada pola tertentu maka mengindikasikan telah terjadi heterokedastisitas, namun jika tidak ada pola yang 
jelas serta titik-titik menyebar diatas dan dibawah angka nol pada sumbu $\mathrm{Y}$, maka tidak terjadi heterokedastisitas (Ghozali, 2013).

\subsubsection{Analisis Regresi Berganda}

Analisis yang digunakan dalam penelitian ini adalah analisis regresi berganda, yaitu dengan melihat faktor-faktor yang mempengaruhi integritas laporan keuangan. Model yang digunakan dalam penelitian iini adalah sebagai berikut

$$
\mathrm{Y}=\mathrm{a}+\mathrm{b}_{1} \mathrm{X}_{1}+\mathrm{b}_{2} \mathrm{X}_{2}+\mathrm{b}_{3} \mathrm{X}_{3}+\varepsilon
$$

$\begin{array}{ll}\text { Keterangan: } & \\ \mathrm{Y} & =\text { Integritas laporan keuangan } \\ \mathrm{a} & =\text { Konstanta } \\ \mathrm{b}_{1} \mathrm{~b}_{2} \mathrm{~b}_{3} & =\text { Koefisien regresi } \\ \mathrm{X} 1 & =\text { Komite Audit } \\ \mathrm{X} 2 & =\text { Reputasi KAP } \\ \mathrm{X} 3 & =\text { Leverage } \\ \mathrm{e} & \end{array}$

\subsubsection{Pengujian Hipotesis}

\subsubsection{Uji Parsial (Uji t)}

Uji statistik t menunjukkan seberapa jauh pengaruh satu variabel penjelas atau independen secara individual dalam menerangkan vaiansi variabel dependen dan digunakan untuk mengetahui ada atau tidaknya pengaruh masing masing variabel independen secara individual terhadap variabel dependen yang diuji pada tingkat signifikansi 0,05. Jika signifikansi t >0,05 maka Ha ditolak namun jika signifikansi $\mathrm{t}<0,05$ maka Ha diterima dan berarti terdapat pengaruh yang signifikan antara variabel independen dengan variabel dependen (Ghozali, 2013:101).

\subsubsection{Uji Signifikansi Simultan (Uji Statistik F)}

Uji statistik F pada dasarnya menunjukkan apakah semua variabel independen atau bebas yang dimasukkan dalam model mempunyai pengaruh secara bersama-sama terhadap variabel dependen. Jika nilai signifikansinya $\mathrm{F}<0,05$ maka Ha diterima dan jika nilai signifikansinya $\mathrm{F}>0,05$ maka Ha ditolak.

\subsubsection{Uji Koefisien Determinasi}

Untuk beberapa penelitian koefisien determinasi lebih baik menggunakan adjusted $\mathrm{R}^{2}$ bisa naik dan turun apabila ada tambahan model dalam penelitian, jika nilai ditemukan negatif maka akan dianggap sebagai 0 . Secara matematis jika $R^{2}=1$, maka adjusted $R^{2}=1$ sedangkan jika $R^{2}=0$, maka adjusted $\mathrm{R}^{2}=(\mathrm{I}-\mathrm{k}) /(\mathrm{n} / \mathrm{k})$. Jika $\mathrm{k}>1$, maka adjusted $\mathrm{R}^{2}$ akan bernilai negatif (ghozali,2013:97).

\section{Hasil Penelitian Dan Pembahasan}

\subsection{Hasil Penelitian \\ 4.1.1 Gambaran Umum Penelitian}

Tabel 4.1 Pemilihan Sampel 


\begin{tabular}{|l|c|}
\hline Kriteria Sampel & Jumlah \\
\hline $\begin{array}{l}\text { Populasi Perusahaan manufaktur yang terdaftar di BEI pada tahun 2015- } \\
2017 .\end{array}$ & $\mathbf{1 4 3}$ \\
\hline Perusahaan yang mengalami kerugian periode 2015-2017. & $(40)$ \\
\hline $\begin{array}{l}\text { Laporan keuangan perusahaan manufaktur disajikan dalam mata uang } \\
\text { rupiah 2015-2017 }\end{array}$ & $(46)$ \\
\hline $\begin{array}{l}\text { Perusahaan tidak memiliki data tersedia lengkap yang diperlukan untuk } \\
\text { menghitung komite audit, reputasi KAP, leverage dan integritas laporan } \\
\text { keuangan }\end{array}$ & 31 \\
\hline Jumlah sampel yang terseleksi & $\mathbf{9 3}$ \\
\hline Jumlah Sampel yang Terseleksi dikali 3 Tahun Pengamatan & \\
\hline
\end{tabular}

Sumber : Data diolah peneliti, 2019

Berikut ini adalah nama-nama perusahaan sampel dalam penelitian ini:

Tabel 4.2 Sampel Penlitian

\begin{tabular}{|l|l|l|}
\hline NO & NAMA PERUSAHAAN & KODE \\
& & \\
\hline 1 & Akasha Wira International Tbk & ADES \\
\hline 2 & Argha Karya Prima Industry Tbk & AKPI \\
\hline 3 & Asiaplast Industries Tbk & APLI \\
\hline 4 & Astra International Tbk & ASII \\
\hline 5 & Sepatu Bata Tbk & BATA \\
\hline 6 & Budi Starch and Sweetener Tbk & BUDI \\
\hline 7 & Chitose Internasional Tbk & CINT \\
\hline 8 & Duta Pertiwi Nusantara & DPNS \\
\hline 9 & Ekadharma International Tbk & EKAD \\
\hline 10 & Gudang Garam Tbk & GGRM \\
\hline 11 & Hanjaya Mandala Sampoerna Tbk & HMSP \\
\hline 12 & Champion Pasific Indonesia Tbk & IGAR \\
\hline 13 & Intan Wijaya International Tbk & INCI \\
\hline 14 & Indofood Sukses Makmur Tbk & INDF \\
\hline 15 & KMI Wire and Cable Tbk & KBLI \\
\hline 16 & Kino Indonesia Tbk & KINO \\
\hline 17 & Kalbe Farma Tbk & KLBF \\
\hline 18 & Mayora Indah Tbk & MYOR \\
\hline 19 & Pelangi Indah Canindo Tbk & PICO \\
\hline 20 & Nippon IndosariCorporindo Tbk & ROTI \\
\hline 21 & Asahimas Flat Glass Tbk & AMFG \\
\hline 22 & Arwana Citra Mulia Tbk & ARNA \\
\hline 23 & Charoen Pokphand Indonesia Tbk & CPIN \\
\hline 24 & Kedawung Setia Industrial Tbk & KDSI \\
\hline 25 & Multi Bintang Indonesia Tbk & \\
\hline & & MLBI \\
\hline & & \\
\hline $12 k$ & \\
\hline & & \\
\hline & & \\
\hline & & \\
\hline
\end{tabular}




\subsection{Analisi Data}

\begin{tabular}{|l|l|l|}
\hline 26 & Industri Jamu \& Farmasi Sido Muncul Tbk & SIDO \\
\hline 27 & Selamat Sempurna Tbk & SMSM \\
\hline 28 & Surya Toto Indonesia Tbk & TOTO \\
\hline 29 & Nusantara Inti Corpora Tbk & UNIT \\
\hline 30 & Unilever Indonesia Tbk & UNVR \\
\hline 31 & Wismilak Inti Makmur Tbk & WIIM \\
\hline
\end{tabular}

Sumber: Data yang diolah Peneliti, 2019 (Lampiran A.1)

\subsubsection{Analisis Statistik Deskriptif}

Tabel 4.3

\begin{tabular}{|l|l|l|l|l|l|}
\hline \multicolumn{7}{|c|}{ Descriptive Statistics } \\
\hline & N & $\begin{array}{c}\text { Minim } \\
\text { um }\end{array}$ & $\begin{array}{c}\text { Maximu } \\
\mathrm{m}\end{array}$ & Mean & Std. Deviation \\
\hline ILK & 93 & .01 & 225.41 & 7.0034 & 26.15624 \\
\hline KOM_AUDIT & 93 & 2 & 33 & 6.69 & 5.517 \\
\hline REP_KAP & 93 & 0 & 1 & .48 & .502 \\
\hline LEVERAGE & 93 & .00 & 17.41 & .9207 & 1.82302 \\
\hline $\begin{array}{l}\text { Valid N } \\
\text { (listwise) }\end{array}$ & 93 & & & & \\
\hline
\end{tabular}

Sumber: Hasil Pengujian Data, 2019 (Lampiran B.1)

\subsubsection{Uji Asumsi Klasik}

\subsubsection{Uji Normalitas Data}

Gambar 4.1 Hasil Uji Normalitas

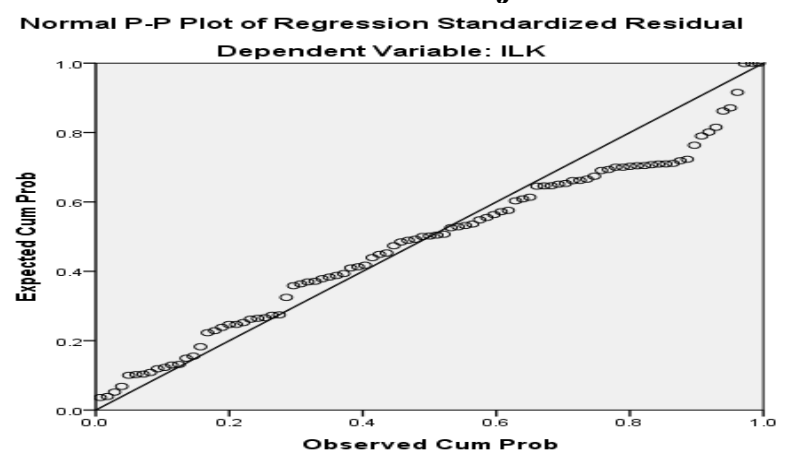

Sumber: Hasil Pengujian Data, 2019 (Lampiran B.1) 


\section{Gambar 4.2. Hasil Uji Normalitas Grafik Histogram}

Histogram

Dependent Variable: ILK

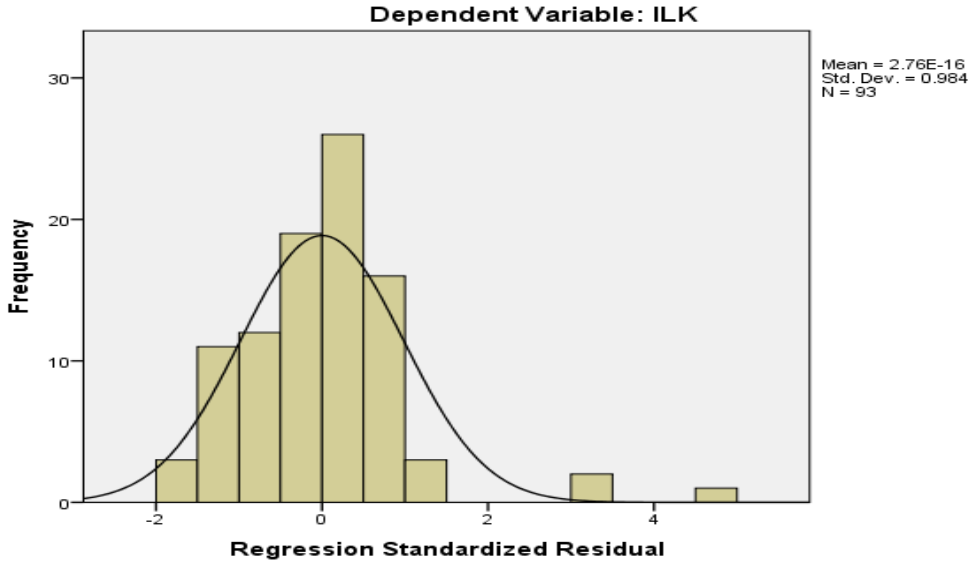

Gambar 4.3. Hasil Uji Normalitas Grafik Normal Plot Normal P-P Plot of Regression Standardized Residual

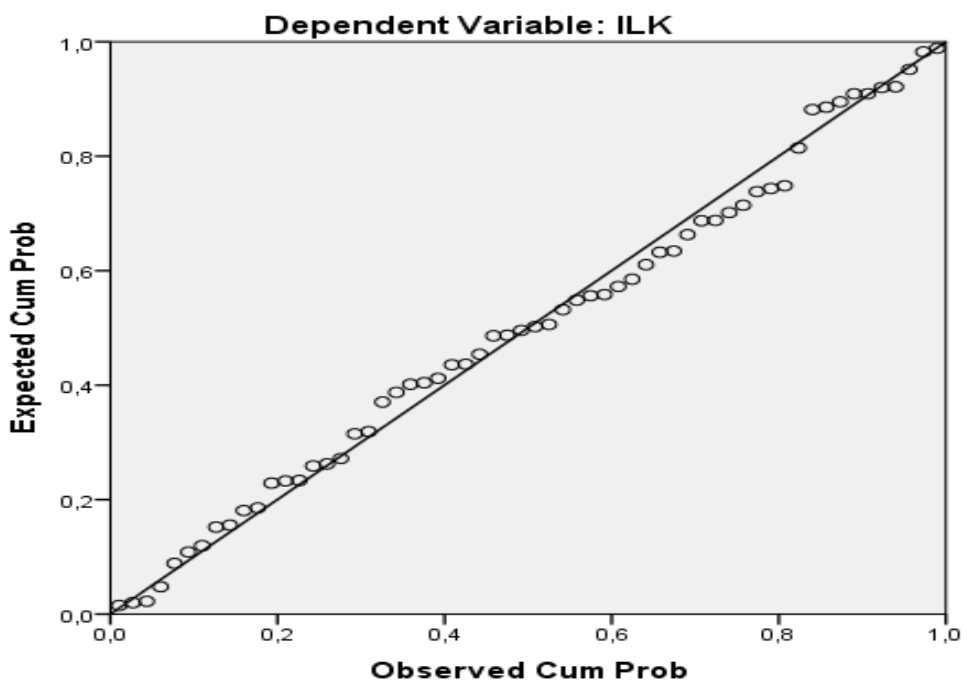

Gambar 4.4. Hasil Uji Normalitas Grafik Histogram

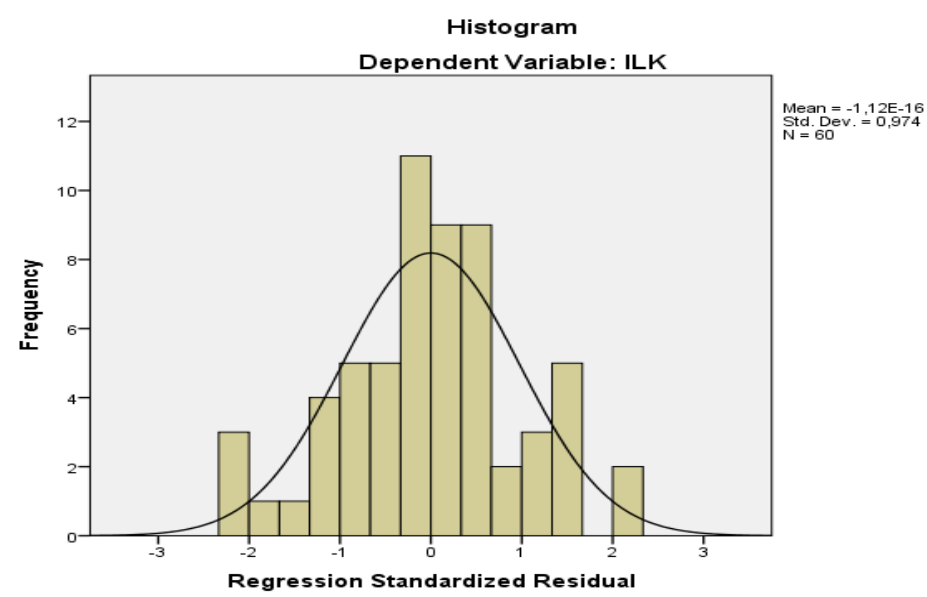

\subsubsection{Uji Multikolinieritas}

Tabel 4.5

Vol : 8, No : 2, 2020

Jurnal Akuntansi dan Perpajakan Indonesia UNIMED 


\begin{tabular}{|l|l|l|c|c|c|c|}
\hline \multicolumn{9}{|c|}{ Coefficientsa } \\
\hline \multirow{2}{*}{ Model } & \multicolumn{3}{c|}{ Correlations } & \multicolumn{2}{c|}{ Collinearity Statistics } \\
\cline { 3 - 7 } \multicolumn{2}{|c|}{} & $\begin{array}{c}\text { Zero- } \\
\text { order }\end{array}$ & $\begin{array}{c}\text { Partia } \\
1\end{array}$ & Part & Tolerance & VIF \\
\hline \multirow{3}{*}{1} & (Constant) & & & & & \\
\cline { 2 - 7 } & KOM_AUDIT &, 046 &, 090 &, 078 &, 996 & 1,004 \\
\cline { 2 - 7 } & REP_KAP &, 429 &, 439 &, 419 &, 996 & 1,004 \\
\cline { 2 - 7 } & LEVERAGE &,- 297 &,- 312 &,- 281 &, 996 & 1,004 \\
\hline
\end{tabular}

Sumber: Hasil Pengujian Data, 2019 (Lampiran B.2)

\subsubsection{Uji Heterokedastisitas}

\section{Gambar 4.5}

\section{Hasil Uji Heterokedastisitas Grafik Scatterplots}

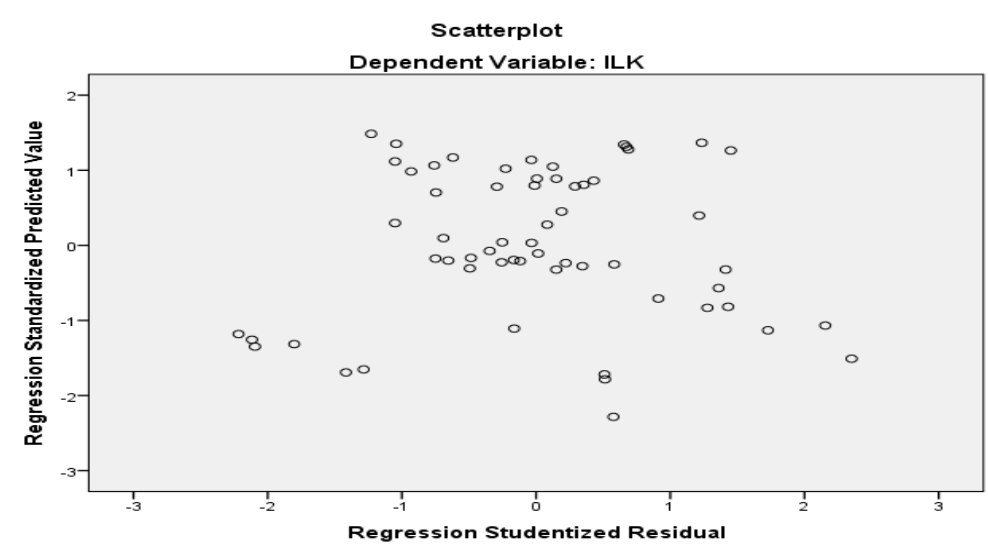

\subsubsection{Uji Autokorelasi}

Tabel 4.6 Hasil Uji Autokorelasi

\begin{tabular}{|l|c|}
\hline \multicolumn{1}{|c|}{ Runs Test } \\
\hline Test Value ${ }^{\mathrm{a}}$ & Unstandardized Residual \\
\hline Cases $<$ Test Value &,- 00386 \\
\hline Cases >= Test Value & 30 \\
\hline Total Cases & 30 \\
\hline Number of Runs & 60 \\
\hline Z & 34 \\
\hline Asymp. Sig. (2-tailed) &, 781 \\
\hline
\end{tabular}

Sumber: Hasil Pengujian Data, 2019 (Lampiran B.3)

\subsubsection{Analisis Regresi Berganda}

Tabel 4.7 Hasil Uji Regresi Berganda 
Pengaruh Komite Audit, Reputasi Kap, Dan Leverage Terhadap Integritas Laporan Keuangan Pada Perusahaan Manufaktur Yang Terdaftar Di Bursa Efek Indonesia Tahun 2015- 2017

\begin{tabular}{|c|c|c|c|c|c|c|}
\hline \multicolumn{7}{|c|}{ Coefficients $^{\mathrm{a}}$} \\
\hline \multirow{2}{*}{\multicolumn{2}{|c|}{ Model }} & \multicolumn{2}{|c|}{$\begin{array}{l}\text { Unstandardized } \\
\text { Coefficients }\end{array}$} & \multirow{2}{*}{$\begin{array}{c}\begin{array}{c}\text { Standardize } \\
\mathrm{d} \\
\text { Coefficients }\end{array} \\
\text { Beta }\end{array}$} & \multirow[t]{2}{*}{$\mathrm{t}$} & \multirow[t]{2}{*}{ Sig. } \\
\hline & & $\mathrm{B}$ & Std. Error & & & \\
\hline \multirow[t]{4}{*}{1} & (Constant) &,- 601 & ,601 & & $-1,001$ &, 321 \\
\hline & KOM_AUDIT & ,066 & ,097 & ,078 & ,679 & ,500 \\
\hline & REP_KAP & 1,356 & ,371 & ,420 & 3,660 &, 001 \\
\hline & LEVERAGE &,- 957 & ,389 &,- 282 & $-2,457$ & ,017 \\
\hline
\end{tabular}

Sumber: Hasil Pengujian Data, 2019 (Lampiran B.4)

\subsubsection{Uji Hipotesis}

4.2.4.1 Uji Simultan (Uji F)

Tabel 4.8 Hasil Uji Simultan (Uji F)

\begin{tabular}{|c|c|c|c|c|c|c|}
\hline \multicolumn{7}{|c|}{ ANOVA $^{a}$} \\
\hline \multicolumn{2}{|c|}{ Model } & $\begin{array}{l}\text { Sum of } \\
\text { Squares }\end{array}$ & Df & $\begin{array}{l}\text { Mean } \\
\text { Square }\end{array}$ & $\mathrm{F}$ & Sig. \\
\hline \multirow[t]{3}{*}{1} & $\begin{array}{l}\text { Regressio } \\
n\end{array}$ & 41,470 & 3 & 13,823 & 6,805 &, $001^{\mathrm{b}}$ \\
\hline & Residual & 113,754 & 56 & 2,031 & & \\
\hline & Total & 155,224 & 59 & & & \\
\hline
\end{tabular}

Sumber: Hasil Pengujian Data, 2019 (Lampiran B.4)

\subsubsection{Uji Parsial (Uji T)}

Tabel 4.9 Hasil Uji Parsial (Uji T)

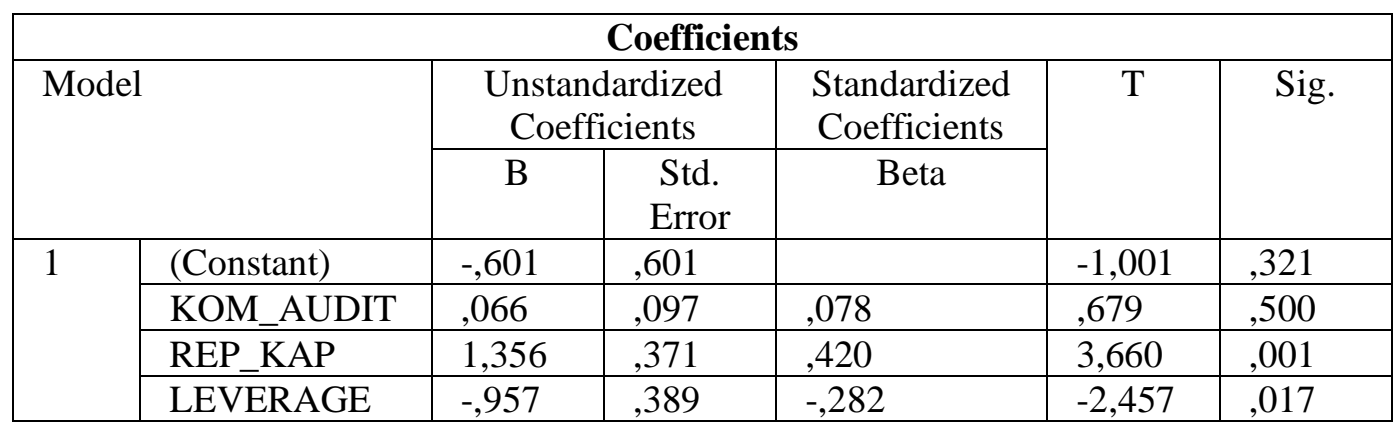

a. Dependent Variable: ILK

Sumber: Hasil Pengujian Data (Lampiran B.4)

\subsubsection{Koefisien Determinasi (R2)}

Tabel 4.10 Hasil Uji Koefisien Determinasi

\section{Model Summary $^{\mathrm{b}}$}




\begin{tabular}{|c|c|c|c|c|}
\hline $\begin{array}{l}\text { Mod } \\
\text { el }\end{array}$ & $\mathrm{R}$ & $\begin{array}{c}\mathrm{R} \\
\text { Square }\end{array}$ & $\begin{array}{l}\text { Adjusted R } \\
\text { Square }\end{array}$ & Std. Error of the Estimate \\
\hline 1 &, $517^{\mathrm{a}}$ & 267 & 228 & 1,42525 \\
\hline
\end{tabular}

Sumber: Hasil Pengolahan Data (Lampiran B.4)

\subsection{Pembahasan Hasil Penelitian}

\subsubsection{Pengaruh Komite Audit Terhadap Integritas Laporan Keuangan}

Berdasarkan uji hipotesis tmenunjukkan nilai $\mathrm{T}_{\text {hitung }} 0,679<$ nilai $\mathrm{T}_{\text {tabel }} 2,003(0,679<2,00324)$ dan nilai signifikansi $0,500>0,05$. Hal ini menunjukkan bahwa komite audit yang diukur dengan frekuensi rapat komite audit tidak berpengaruh terhadap integritas laporan keuangan. Tentu hal ini menunjukkan bahwa komite audit belum berfungsi dengan baik didalam menjalankkan tanggung jawab pada bidang, yaitu: a. pengawasan dalam penyusunan laporan keuangan (financial reporting); b. Tata kelola perusahaan; c. Pengawasan perusahaan (corporate control) sehingga akan berdampak kepada integritas laporan keuangan yang disajikan. Hal ini juga sejalan dengan penelitian Ahmad sauqi dan sakram (2017) yang menyatakan bahwa komite audit tidak berpengaruh terhadap integritas laporan keuangan dan juga dalam penelitian hirdingsih (2010) menunjukkan tidak adanya pengaruh yang signifikan antara komite audit dengan integritas laporan keuangan.

\subsubsection{Pengaruh Reputasi Kap Terhadap Integritas Laporan Keuangan}

Hasil uji t pada variabel reputasi kap menghasilkan nilai Thitung 3,660 > nilai Ttabel2,00324 (3,660 $>2,00324$ ) dan nilai signifikansi 0,001 <0,05; yang berarti reputasi kap berpengaruh signifikan terhadap integritas laporan keuangan. Hal ini menunjukkan bahwa reputasi Kantor Akuntan Publik berhasil dalam memberikan sinyal kepercayaan kepada pihak yang berkepntingan atas legalitas dan integritas opini yang independen dikeluarkan akuntan dalam meyakini keandalan informasi keuangan yang disampaikan pihak manajemen sehingga akan meningkatkan integritas laporan keuangan.

\subsubsection{Pengaruh Leverage Terhadap Integritas Laporan Keuangan}

Hasil uji t pada variabel leverage menghasilkan nilai Thitung $-2,457<$ nilai Ttabel $2,00324(-2,457$ $<2,00324)$ dan nilai signifikansi $0,017<0,05$; yang berarti leverage berpengaruh signifikan terhadap integritas laporan keuangan. Hal ini berarti manajemen telah berhasil mengelola utang nya dan berhasil meyakinkan calomn investor melalui rencana bisnis dan prospek perusahaan dimasa mendatang. Hasil penelitian sejalan dengan fajaryani (2015) dan Gayatri dan Saputra (2013).

\subsubsection{Pengaruh Komite Audit, Reputasi KAP, dan Leverage Terhadap Integritas Laporan Keuangan.}

Berdasarkan hasil pengolahan SPSS pada tabel 4.9, dapat dilihat bahwa $F_{\text {hitung }}$ adalah sebesar 6,805 dengan nilai $F_{\text {tabel }}$ adalah sebesar 2,76. Hal ini menunjukkan nilai $F_{\text {hitung }} 6,805>F_{\text {tabel }} 2,76$, sedangkan nilai signifikansi sebesar 0,001 <0,05. Maka dapat disimpulkan bahwa komite audit, leverage, dan reputasi KAP berpengaruh secara simultan terhadap integritas laporan keuangan. Hasil ini menunjukkan bahwa komite audit, leverage, dan reputasi KAP merupakan faktor-faktor yang harus diperhatikan perusahaan dalam meningkatkan integritas laporan keuangan sehingga laporan keuangan yang disajikan dapat dipercaya. Hal ini juga didukung oleh hasil koefisien determinasi (adjusted $R$ Square) sebesar 22,8\%. Hal ini mengartikan bahwa variabel komite audit, reputasi kap, dan leverage mempengaruhi integritas laporan keuangan sebesar 22,8\% sedangkan $77,2 \%$ lainnya didukung oleh faktor-faktor lain.

\section{Kesimpulan}

Berdasarkan permasalahan penelitian, kajian teori, hasil penelitian, dan pembahasan, maka dapat disimpulkan sebagai berikut:

1. Komite audit yang diukur dengan frekuensi rapat komite audit tidak berpengaruh terhadap integritas laporan keuangan dengan tingkat signifikansi 0,500. Hal ini berarti bahwa komite audit belum berfungsi dengan baik dalam menjalankan tanggung jawab pada bidang yaitu; a. 
Pengawasan dalam penyusunan laporan keuangan, b. Tata kelola perusahaan; c. Pengawasan perusahaan sehingga akan berdampak pada integritas laporan keuangan.

2. Reputasi KAP secara parsial berpengaruh terhadap integritas laporan keuangan dengan nilai signifikansi 0,001. Hal ini menunjukkan bahwa reputasi Kantor Akuntan Publik berhasil dalam memberikan sinyal kepercayaan kepada pihak yang berkepntingan atas legalitas dan integritas opini yang independen yang dikeluarkan akuntan dalam meyakini keandalan informasi keuangan yang disampaikan pihak manajemen sehingga akan meningkatkan integritas laporan keuangan.

3. Leverage secara parsial menunjukkan berpengaruh signifikan terhadap integritas laporan keuangan dengan nilai signifikansi 0,017. Hal ini berarti manajemen telah berhasil mengelola utangnya dan berhasil menyakinkan calon investor melalui rencana bisnis dan prospek perusahaan dimasa mendatang

Hasil penelitian secara simultan dapat disimpulkan bahwa komite audit, reputasi KAP dan leverage berpengaruh secara simultan terhadap integritas laporan keuangan. Hasil ini menunjukkan bahwa komite audit, reputasi KAP dan leverage merupakan faktor-faktor yang harus diperhatikan perusahaan dalam meningkatkan integritas laporan keuangan sehingga laporan keuangan yang disajikan dapat dipercaya. Sesuai teori agency bahwa tujuan perusahaan bisa meningkat ketika manajer (agen) memiliki motivasi untuk menjalin hubungan baik dengan pemegang saham (prinsipal) dalam mencapai tujuan perusahaan, khususnya peningkatan integritas laporan keuangan.

\section{Reverensi}

Aljufri. 2014. Dampak Audit Quality dan Corporate Governance Terhadap Integritas Laporan Keuangan. Jurnal ekonomi dan bisnis, Vol. 11 No.2

Antovandra, Faradigma Bagus. 2017. Analisis Pengaruh Good Corporate Governance, Pengungkapan Corporate Social Responsibility, Growth Dan Size Terhadap Nilai Perusahaan Pada Industri Sektor Perbankan.

Atiningsih Suci, Yohana Kus Suparwati. 2018. Pengaruh Corporate Governance dan Leverage Terhadap Integritas Laporanb Keuangan. Jurnal ilmu manajemen dan akuntansi terapan. Vol. 9 No. 2

Astria, Tia. 2011. Analisis Penagruh Audit Tenure, Structure Corporate Governance dan Ukuran KAP terhadap Integritas Laporan Keuangan. E journal. Semarang. Universitas Dipenogoro.

Astinia, Imah. 2013. Pengaruh Corporate Governance, Kualitas Audit dan Ukuran Perusahaan terhadap Integritas Laporan Keuangan pada perusahaan disektor keuangan yang terdaftar di BEI). Skripsi. Jakarta: UIN Syarif Hidayatullah

Bilquita, Polli 2016. Kasus Pelanggaran Xerox Corporation. http://bilquitapolii.blogspot.com/2016/11/kasus-pelanggaran-xerox-corporation.html.(24 april 2019)

Deil, Amelia Siska. 2014. Enron, Skandal besar perusahaan energi yang cekik investor. https://www.liputan6.com/bisnis/read/2031867/enron-skandal-besar-perusahaan-energiyang-cekik-investor 
Detik, hot.2012. Kasus Tyco Internasional 2002. https://reader choice.detik.com/detik hot ponds raiskasus-penipuan-saham terbesar-sepanjang-sejarah

Eisenhardt, Kathleen M. 1989. "Agency Theory: An Assessment and Review. The Academy of Management Review.” Vol. 14, No.1 Hal: 57-74.

Forum for Corporate Governance Indonesia. 2001. "Peranan Dewan Komisaris dan Komite Audit dalam Pelaksanaan Corporate Governance”. Seri Tata Kelola Perusahaan. Jilid II. http://www.fcgi.org.id. (15 Maret 2019).

Forum for Corporate Governance in Indonesia (FCGI). 2011. "What is Corporate Governance. "http://www.fcgi.or.id/corporate-governance/about-good-corporategovernance.html.(15 Maret 2019)

Fajaryani, Atik. 2015. Analisis Faktor-faktor yang mempengaruhi integritas laporan keuangan ( Studi Empiris pada perusahaan pertambangan yang terdaftar di bursa efek indonesia periode 2008-2013). Skripsi .Yogyakarta.

Ghozali, Iman. 2013. Aplikasi Analisis Multivariate dengan Program SPSS. Semarang: Badan Penerbit Universitas Diponegoro.

Gayatri, Ida Ayu Sri dan I Dewa Gede Dharma Suputra, 2013. Pengaruh Corporate Governance, ukuran perusahaan, dan leverage terhadap integritas laporan keuangan. E-journal Akuntansi. Universitas Udayana 5.2:345-360

Hirdiningsih, Pancawati. 2010. Pengaruh Independensi, Corporate Governance Governance dan Kualitas Audit terhadap integritas laporan keuangan. Kajian Akuntansi, februari 2010, Vol.2 No.1, Hal 61-76

Jama'an. 2008. Pengaruh Mekanisme Corporate Governanace, Dan Kualitas Kantor Akuntan Publik Terhadap Integritas Informasi Laporan Keuangan. Tesis. Semarang: Universitas Dipenogoro.

Jensen, Michael C. Dan W.H. Meckling. (1976). “ Theory Of the Firm: Managerial Behavior, Agency Cost and Awnership Structure”. Journal Of Financial Economics. Vol. 3. No 4, pp. 305-360

Kalsum, Umi. 2015. Kasus Pelanggaran Etika Profesi Akuntansi. http:///kasus-pelanggaran-etikaprofesi. ( 02 Februari 2019).

Keputusan Menteri Badan Usaha Milik Negara Nomor: Kep-117/M-MBU/2002 Pasal 4 Komite Nasional Kebijakan Governance. 2006. Pedoman Umum Good Corporate Governance Indonesia.

Mayangsari, sekar. 2003. Analsiis Pengaruh Independensi, Kualitas Audit, serta mekanisme corporate governance terhadap integritas laporan keuangan. Simposium Nasional Akuntansi VI.

Nurdiniah, Dade. 2017. Effect of good corporate governance, Kap reputatation and leverage on integrity of financial statements. International Journal of Economics and Financial. Vol.7

Nicolin, Oktavia dan Sabeni, Arifin. 2013. Pengaruh struktur corporategovernance, audit tenure, dan spesialisasi industri auditor terhadap integritas laporan keuangan. Jurnal akuntansi. Vol.2 No.2

Pamudji, Sugeng dan Aprillya Trihartati. 2010. Pengaruh Independensi Dan Efektivitas Komite Audit Terhadap Manajemen Laba.Jurnal Dinamika Akuntansi. Vol. 2, No. 1, Hal.21-29. 
Randhy, Muhammad 2016.Kasus Pelanggaran Etika Skandal Manipulasi Laporan Keuangan PT. KAI 206. http://mrandhy8.blogspot.com/2016/01/kasus-pelanggaran-etka-skandal.html. (16Maret 2019)

Perlantino, Januar. 2017 Pengaruh Corporate Governance, Kualitas KAP, Firm Size, dan Leverage Terhadap Integritas Laporan Keuangan Pada Perusahaan Real Estate Yang Terdaftar di BEI. Skripsi.Medan: Universitas Negeri Medan

Sanusi, Anwar. 2016. Metodologi penelitian Bisnis. Jakarta: Salemba Empat

Sauqi, Ahmad dkk . 2017. The effect of corporate governance mecahnism, auditor indepence,audit quality to integrity of financial statements. International Conference and Call for Papers

Savitri, Enni. 2016. Konservatisme Akuntansi. Yogyakarta. Pustaka Sahila Yogyakarta.

Siddiqui, Muhammad Faisal.2013. Internal Corporate Governance Mechanisms and agency cost: Evidence from large KSE Listed firms. European Journal of Business and Management. ISSN 2222-1905. Vol.5, No.23

Sinaga, Elfrida.2014. pengaruh Mekanisme Corporate Governance, kualitas Kantor Akuntan Publik, Audit Tenure dan Ukuran Perusahaan terhadap Integritas Laporan Keuangan Pada Perusahaan Manufaktur yang terdaftar di BEI. Skripsi. Medan: Universitas Negeri Medan

Siahaan, Septony B. 2017. Pengaruh good, Corporate Governance, Dan Kualitas KAP Terhadap Integritas Laporan Keuangan. Jurnal akuntansi dan keuangan, Vol 1 No.1

Situmeang, Chandra. 2014. Manajemen Keuangan. Medan: Unimed Press

Verya, Endy. 2017. Analisis Pengaruh, ukuran perusahaan, Leverage, dan Good Corporate Governance terhadap Integritas Laporan Keuangan. Jurnal akuntansi, Vol. 4 No. 1

Watts, Ross L.2003. Conservatism in Accounting Part 1 : Explanations and Impliations. Accounting Horizons. Vol.17, No. 3

Watts, Ross L.; Zimmerman, Jerold L.1990. Positive Accounting Theory: A Ten Year Perpective. The Accounting Review. Vol. 65. No.1

www.idx.co.id 